\title{
Analisis Gen 12SrRNA Dari DNA Mitochondria Kelelawar Pemakan Buah Chironax Melanocephalus (Chiroptera: Pteropodidae) Di Taman Nasional Gunung Halimun
}

\author{
Analysis Of 12SrRNA Gene Region Mitochondrial DNA Of Fruit Bat Chironax \\ Melanocephalus (Chiroptera: Pteropodidae) In Gunung Halimun National Park
}

\section{Syamsul Arifin Zein dan Maharadatunkamsi}

Pusat Penelitian Biologi, LIPI

\begin{abstract}
A study on genetic variation of the high mountain fruit bat (Chironax melanocephalus) was conducted in Gunung Halimun National Park. DNA total from liver tissues were extracted and fragment of the 12SrRNA gene region of mitochondrial DNA were amplified by Polymerase Chain Reaction (PCR). Nucleotide sequence of the PCR products were determined by automated sequencer. Seven haplotype were found among 20 individuals from 6 localities, namely: South Halimun Mountain, Kendeng Mountain, Botol Mountain, Pasir Cangkuang Mountain, Kencana Mountain, and Buligir Putih Mountain. Haplotype diversity and nucleotide diversity were 0.76 and 0.0222. DNA distances values ranged from 0.0028 to 0.0202 .
\end{abstract}

Kata kunci: Chironax melanocephalus, 12SrRNA mitokondria, keragaman genetik.

Diterima: 13 Mei 2002, disetujui: 14 Nopember 2002

\section{Pendahuluan}

Kelelawar pemakan buah (Pteropodidae) berfungsi sebagai penyebar biji dan ikut membantu dalam proses penyerbukan bunga. Peranannya dalam ekosistem adalah menjaga keseimbangan ekologi dan mempunyai arti penting dalam proses regenerasi hutan (Kitchener et al., 1990; Alikodra, 1990; Fujita dan Tuttle, 1991). Chironax melanochephalus sebagai salah satu jenis kelelawar pemakan buah mempunyai penyebaran yang luas, meliputi Thailand, Semenanjung Malaysia, Sumatra, Jawa, Lombok dan Sulawesi. Kelelawar ini bertubuh kecil dengan bobot badan sekitar 16 gr dan panjang lengan sayap bawah (fore arm) 42 - $47 \mathrm{~mm}$ (Payne et al., 1985; Suyanto et al., 2002).

Taman Nasional Gunung Halimun dikenal sebagai kawasan konservasi hutan primer hujan tropis pegunungan terbesar yang masih tersisa di pulau Jawa dengan luas sekitar
40.000 ha. Simbolon dan Mirwanto (1997) dengan mengikuti klasifikasi hutan pegunungan (Steenis, 1972), membagi kawasan Taman Nasional Gunung Halimun menjadi 3 mintakat, yaitu mintakat kaki pegunungan (colline forest zone) dengan ketinggian 500-1000 m dpl, mintakat subpegunungan (submontane forest zone) dengan ketinggian 1000-1500 m dpl, dan mintakat pegunungan (mountain forest zone) dengan ketinggian diatas $1500 \mathrm{~m}$ dpl. Selain itu juga dilaporkan bahwa keanekaragaman hayati di kawasan ini sangat besar, tercatat paling tidak 25.000 spesies tumbuhan berbunga yang merupakan $10 \%$ dari jumlah tumbuhan berbunga di dunia.

Dominasi populasi Chironax melanocephalus di kawasan Taman Nasional Gunung Halimun terdapat pada mintakat subpegunungan, yaitu pada ketinggian 1200-1400 m dpl (Suyanto dan Sinaga, 1998). Topografi kawasan ini yang terdiri dari daerah 
pegunungan, memungkinkan terjadinya isolasi alam bagi sebagian besar mamalia kecil. Hal ini akan dapat menghambat terjadinya aliran gen dari satu lokasi ke lokasi lain dalam kawasan taman nasional ini. Oleh sebab itu analisis keragaman genetik dari berbagai populasi sangat menarik untuk diketahui, sehingga dapat digunakan sebagai masukkan dalam menentukan strategi konservasi di Taman Nasional Gunung Halimun.

Aplikasi teknologi DNA dalam analisis keragaman genetik pada tingkat molekuler dengan menggunakan DNA marker, telah digunakan secara luas. Avise (1994) mengatakan bahwa DNA mitokondria banyak digunakan untuk menentukan hubungan kekerabatan berbagai spesies binatang. Genom DNA mitokondria berbentuk sirkuler, pada mamalia berisi 13 gen penyandi protein, 22 gen transfer RNA (tRNA), dan 2 gen ribosoma (rRNA) dengan panjang sekitar 16.000 pasangan basa (Anderson et al., 1981). Sebagian besar gen penyandi protein dari DNA mitokondria seperti sub-unit cytochrome c oxidase, cytochrome b, dan gen ribosoma banyak digunakan dalam kajian populasi genetik maupun filogeni (Shearer et al., 2002). Kajian keragaman genetik Chironax melanocephalus di Taman Nasional Gunung Halimun, dilakukan dengan menggunakan gen 12SrRNA. Gen 12SrRNA merupakan salah satu dari gen ribosoma dari DNA mitokondria. Variasi genetik dari beberapa populasi Chironax melanocephalus dapat menggambarkan hubungan yang terjadi diantara populasi tersebut.

\section{Bahan Dan Cara Kerja}

\section{Koleksi spesimen:}

Spesimen kelelawar dikoleksi dengan menggunakan jaring kabut dari berbagai lokasi di Taman Nasional Gunung Halimun, yaitu: Gunung Pasir Cangkuang, Gunung Kencana, Gunung Kendeng, Gunung Buligir Putih, Gunung Halimun Selatan, dan Gunung Botol
(Gambar 1). Daerah tersebut merupakan kawasan Taman Nasional Gunung Halimun. Kelelawar yang diperoleh kemudian digunakan sebagai koleksi spesimen ilmiah Bidang Zoologi, Pusat Penelitian Biologi LIPI. Sedangkan untuk keperluan analisis DNA diambil sedikit jaringan hati dan dimasukkan ke dalam tabung ependorf 1,5 ml yang berisi $100 \%$ alkohol sebagai pengawet.

\section{Ekstraksi dan Purifikasi DNA :}

Ekstraksi DNA dilakukan dengan mengikuti standard prosedur dari Sambrook et al., (1989). Jaringan berupa hati kelelawar diambil sebanyak $\pm 30 \mathrm{mg}$, dipotong-potong dan digerus sampai halus dengan mortal. Selanjutnya dimasukkan ke dalam tabung ependorf $1,5 \mathrm{ml}$ yang berisi $500 \mu \mathrm{l}$ buffer STE (Salt Tris EDTA) dan di vortex. Setelah itu ditambahkan $20 \mu \mathrm{l} 10 \mathrm{mg} / \mathrm{ml}$ proteinase K dan $50 \mu \mathrm{l}$ 10\% SDS (Sodium Dodecyl Sulphate). Inkubasi dilakukan dengan menggunakan water bath shaker pada temperatur $55^{\circ} \mathrm{C}$ selama 2 jam. Kemudian ditambahkan $50 \mu \mathrm{l} 5$ $\mathrm{M} \mathrm{NaCl}, 400 \mu \mathrm{l}$ fenol, dan $400 \mu \mathrm{l}$ CIAA (Chloroform Isoamil Alcohol), digoyang secara perlahan dengan menggunakan shaker pada temperatur ruang selama 1,5 jam. Selanjutnya disentrifugasi $3.000 \mathrm{rpm}$ selama 5 menit, kemudian supernatan dipindahkan ke tabung baru dan ditambahkan $50 \mu \mathrm{l} 5 \mathrm{M} \mathrm{NaCl}$ serta 1 $\mathrm{ml} 100 \%$ etanol, dikocok dan diinkubasi pada temperatur $-20^{\circ} \mathrm{C}$ selama 1 jam. Sentrifugasi berikutnya pada $8.000 \mathrm{rpm}$ selama 5 menit, kemudian cairan dibuang. Proses selanjutnya ditambah $1 \mathrm{ml} \mathrm{70 \%} \mathrm{etanol,} \mathrm{kemudian}$ disentrifugasi pada 8.000 rpm selama 5 menit. Setelah itu larutan dibuang dan ditiriskan hingga tak ada larutan tertinggal, kecuali ekstrak DNA dan dikeringkan dengan vakum pengering selama $30-60$ menit. Kristal putih yang tertinggal merupakan DNA total, kemudian dilarutkan dalam $50 \mu \mathrm{l}$ TE (TrisEDTA). 


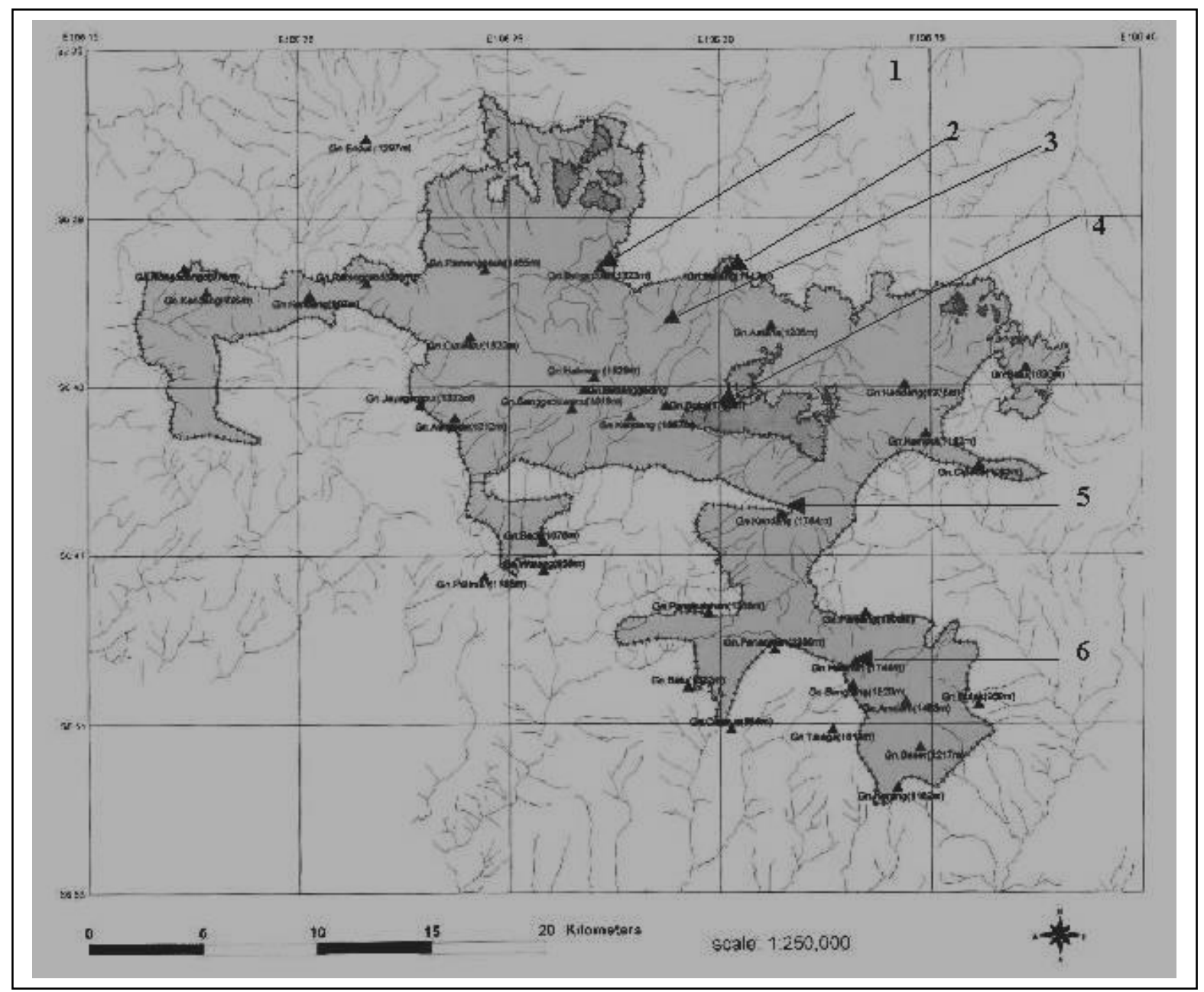

Gambar 1. Peta Taman Nasional Gunung Halimun dan lokasi pengambilan sampel yaitu: Gunung Buligir Putih (1), Gunung Kencana (2), Gunung Pasir Cangkuang (3), Gunung Botol (4), Gunung Kendeng (5), dan Gunung Halimun Selatan (6).

Proses purifikasi dilakukan dengan menambahkan $5 \mu$ RNAase $10 \mathrm{mg} / \mathrm{ml} \mathrm{ke}$ dalam $50 \mu$ DNA hasil ekstraksi, kemudian divortex dan diinkubasi pada $37^{\circ} \mathrm{C}$ selama 3 jam. Setelah proses inkubasi selesai, ditambahkan $200 \mu \mathrm{l}$ air milliQ, $200 \mu \mathrm{l}$ fenol, dan $200 \mu \mathrm{l}$ kloroform. Proses berikutnya digoyang-goyang dengan tangan dan disentrifugasi pada $8.000 \mathrm{rpm}$ selama 10 menit. Supernatan dipindahkan ke tabung baru dan ditambahkan $25 \mu \mathrm{l} 5 \mathrm{M} \mathrm{NaCl}, 500 \mu \mathrm{l}$ etanol absolut dingin dan digoyang perlahan dengan tangan, kemudian diinkubasi pada suhu $-20^{\circ} \mathrm{C}$ selama 1 jam. Proses terakhir disentrifugasi pada $8.000 \mathrm{rpm}$ selama 10 menit kemudian larutan dibuang dan ditiriskan hingga semua larutan habis, kemudian ditambahkan $50 \mu \mathrm{l}$ larutan TE (Tris-EDTA) dan disimpan pada $4^{\circ} \mathrm{C}$ sampai digunakan.

\section{Amplifikasi fragmen DNA}

Gen 12SrRNA dari DNA mitokondria digunakan dalam analisis keragaman genetik Chironax melanocephalus. Amplifikasi fragmen tersebut dengan menggunakan primer universal dengan sekuen sebagai berikut:

L 1091 uni.: 5"CAA ACT GGG ATT AGA TAC CCC ACT AT 3" 
H 1478 uni.: 5"GAG GGT GAC GGG CGG TGT GT 3"Amplifikasi fragmen dari gen 12SrRNA dilakukan dengan Polymerase Chain Reaction (PCR) Perkin Elmer Thermalcycler (type 9600) dengan volume sebanyak $50 \mu \mathrm{l}$ yang berisi $1 \mu \mathrm{l}$ DNA total, $4 \mu \mathrm{l} 2,5 \mathrm{mM}$ dNTP (Amersham Pharmacia Biotech), $4 \mu \mathrm{l}(2,5 \mathrm{p}$ mol) primer L 1091 uni. dan $4 \mu \mathrm{l}(2,5 \mathrm{p}$ mol $)$ primer H 1478 uni., 2,5 unit tag DNA polymerase (Amersham Pharmacia Biotech), 5 $\mu$ l 10x bufer, dan ditambah air milliQ hingga volume total $50 \mu \mathrm{l}$.

Kondisi PCR adalah pre denaturasi $95^{\circ} \mathrm{C}$ selama 5 menit, kemudian denaturasi $95^{\circ} \mathrm{C}$ selama 30 detik, hibridisasi primer pada temperatur $55^{\circ} \mathrm{C}$ selama 30 detik, dan elongasi pada temperatur $72^{\circ} \mathrm{C}$ selama 60 detik dan dilakukan sebanyak 40 siklus. Setelah itu dilakukan pasca elongasi pada temperatur $72^{\circ} \mathrm{C}$ selama 10 menit. Hasil amplifikasi fragmen dari gen 12SrRNA di elektroforesis dengan menggunakan 1\% AGE (Agarose Gel Electrophoresis). Visualisasi hasil elektroforesis menggunakan ethidium bromide dengan bantuan sinar ultra violet. Dokumentasi dilakukan dengan menggunakan kamera polaroid MP4.

\section{Analisis sekuensing:}

Analisis sekuen dari gen 12SrRNA dilakukan secara sebagian (partial) dengan menggunakan Alfexpress DNA Sequencer (Farmacia Biotech) dengan reagen Thermo sequenase fluorescent labelled primer cycle sequencing kit (Amersham Pharmacia Biotech). Program CLUSTALW digunakan dalam multiple alignments sequence. Sedangkan analisis filogeni dari data dasar sekuen tersebut dengan metoda neighborjoining dan kalkulasi distance matrix dengan model Kimura 2-parameter (Kimura, 1980) yang diimplementasikan dalam program DNADIST dari PHYLIP (Phylogeny Inference Package) Versi 3.5c.

\section{Hasil dan Pembahasan}

Analisis gen 12SrRNA dari DNA mitokondria adalah untuk mengetahui variasi genetik dari populasi kelelawar pemakan buah Chironax melanocephalus di Taman Nasional Gunung Halimun. Hasil analisis tersebut meliputi jumlah haplotipe, frekuensi haplotipe, keragaman haplotipe, keragaman nucleotida, dan konstruksi pohon filogeni.

Sekitar 355 runutan basa gen 12SrRNA dari 7 haplotipe yang terdapat di Taman Nasional Gunung Halimun diketahui terdapat 8 situs polimorfik (lihat Gambar 2), yaitu di Gunung Buligir Putih terdapat 1 haplotipe (HF), Gunung Kencana terdapat 2 haplotipe (HC dan HE), Gunung Pasir Cangkuang terdapat 4 haplotipe (HC, $\mathrm{HD}, \mathrm{HE}$, dan $\mathrm{HG}$ ), Gunung Botol terdapat 2 haplotipe (HA dan HB), Gunung Kendeng terdapat 2 haplotipe (HC dan HD) dan Gunung Halimun Selatan. terdapat 1 haplotipe (HC). Frekuensi haplotipe dapat dikatakan relatif hampir sama. Keragaman haplotipe berkisar antara 0,52 0,72 dan keragaman nukleotida sebesar 0,0222 untuk seluruh kawasan Taman Nasional Gunung Halimun (Tabel 1).

Konstruksi pohon filogeni dengan menggunakan metoda Neighbor-joining dapat dilihat pada Gambar 3. Sedangkan jarak genetik dari haplotipe yang diketemukan, yaitu $\mathrm{HA}, \mathrm{HB}, \mathrm{HC}, \mathrm{HD}, \mathrm{HE}, \mathrm{HF}$ dan $\mathrm{HG}$ dapat dilihat pada Tabel 2 . 
Gambar 2. Penyelarasan hasil sekuen gen 12SrRNA dari haplotipe Chironax melanocephalus di Taman Nasional Gunung Halimun .

\begin{tabular}{|c|c|}
\hline $\mathrm{HE}$ & -----TAAGTAGTAAGCACTAACAATACTACTCGCCAGAGAACTACTAGGCAATAGCTTA \\
\hline HD & 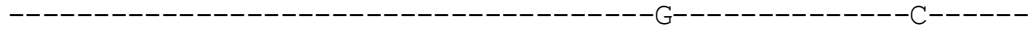 \\
\hline $\mathrm{HC}$ & ----------------------------------------------------------C------ \\
\hline $\mathrm{HF}$ & ------------------------------------------------------ \\
\hline $\mathrm{HA}$ & --------------------------------------------------------C------ \\
\hline HB & $-------------------------------------\mathrm{A}---------------\mathrm{C}------$ \\
\hline \multirow[t]{2}{*}{ HG } & $------------------------------------------------------C------$ \\
\hline & 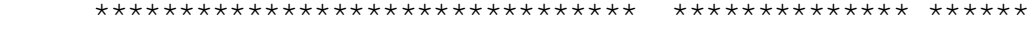 \\
\hline $\mathrm{HE}$ & TAAACTCAAAGGACTATTGTGCGGGTGCTCTTATATCCACTCTAGAGGAGCCTGTTCTAT \\
\hline HD & 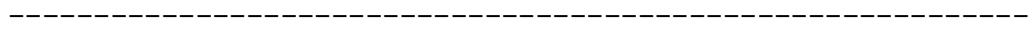 \\
\hline $\mathrm{HC}$ & ---------------------------------------------------------------- \\
\hline $\mathrm{HF}$ & ------------------------------------------------------------------ \\
\hline $\mathrm{HA}$ & 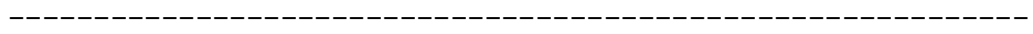 \\
\hline HB & --------------------------------------------------------------- \\
\hline \multirow[t]{2}{*}{ HG } & 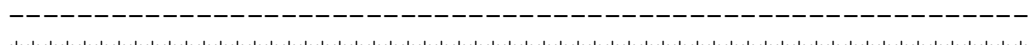 \\
\hline & 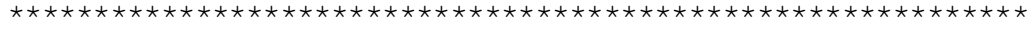 \\
\hline $\mathrm{HE}$ & AАTCGATGAACCCCGATAAACCTCCACCAАCCCTTGCTAATTCAGCCTATATACCGCCAT \\
\hline HD & 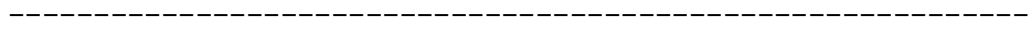 \\
\hline $\mathrm{HC}$ & 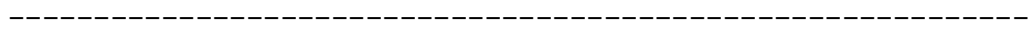 \\
\hline $\mathrm{HF}$ & -------------------------------------------------A \\
\hline $\mathrm{HA}$ & 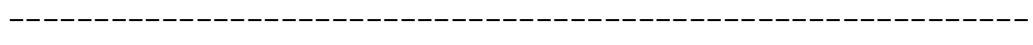 \\
\hline HB & 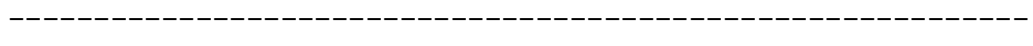 \\
\hline \multirow[t]{2}{*}{ HG } & ------------------------------------------------------------------- \\
\hline & 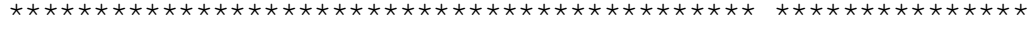 \\
\hline $\mathrm{HE}$ & СTTCCAAGCGAACCCGTAAAAAGGAAACATAGTCAAGCAAGACCATAGGACATAAGGAAA \\
\hline $\mathrm{HD}$ & 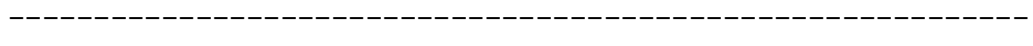 \\
\hline $\mathrm{HC}$ & 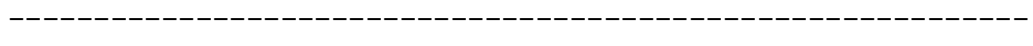 \\
\hline $\mathrm{HF}$ & ----------------------------------------------------------------- \\
\hline $\mathrm{HA}$ & ---------A $-----------------\mathrm{C}--\mathrm{C}------------------------------$ \\
\hline HB & $---------\mathrm{A}-------\mathrm{T}--------\mathrm{C}--\mathrm{C}------------------------------$ \\
\hline \multirow[t]{2}{*}{ HG } & ------------------T-----------C------------------------------ \\
\hline & 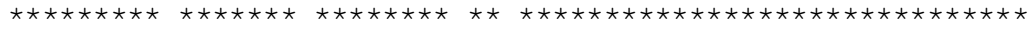 \\
\hline $\mathrm{HE}$ & CGTTAGGTCAAGAGTGTAGACCCATGGGTTTGTGGGATGAGAAATAGGGCTACATATTTC \\
\hline HD & 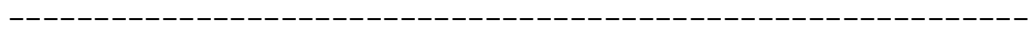 \\
\hline $\mathrm{HC}$ & 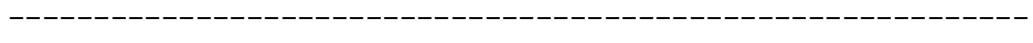 \\
\hline $\mathrm{HF}$ & 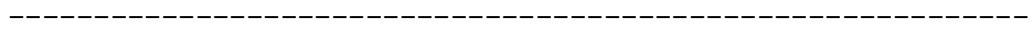 \\
\hline $\mathrm{HA}$ & 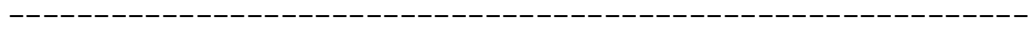 \\
\hline HB & 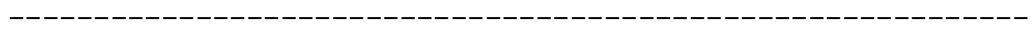 \\
\hline \multirow[t]{2}{*}{ HG } & 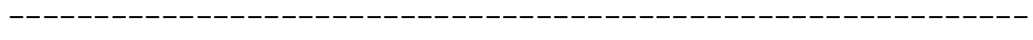 \\
\hline & 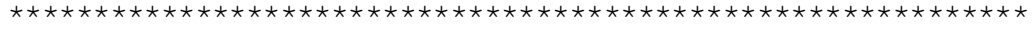 \\
\hline $\mathrm{HE}$ & TTAAACAATAGGAACACTTACGAAAATTTTCGTGAAATCGGTAAAATGGAAGGAGGAT \\
\hline $\mathrm{HD}$ & 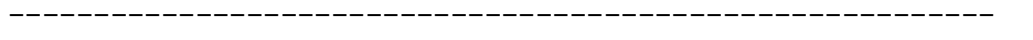 \\
\hline $\mathrm{HC}$ & 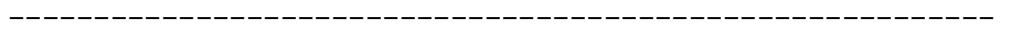 \\
\hline $\mathrm{HF}$ & ------------------------------------------------------------------- \\
\hline $\mathrm{HA}$ & -----T-------------------------------------------------------- \\
\hline HB & -----T---------------------------------------------------- \\
\hline \multirow[t]{2}{*}{ HG } & -----T--------------------------------------------------------- \\
\hline & 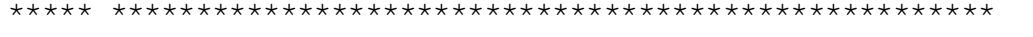 \\
\hline
\end{tabular}


Tabel 1. Frekuensi haplotipe, keragaman haplotipe, dan keragaman nukleotida gen 12SrRNA Chironax melanocephalus dari Taman Nasional Gunung Halimun.

\begin{tabular}{|c|c|c|c|c|c|c|c|c|c|c|}
\hline \multirow{2}{*}{ No. } & \multirow{2}{*}{ Lokasi } & \multicolumn{7}{|c|}{ Frekuensi Haplotipe } & \multirow{2}{*}{$\begin{array}{c}\text { Keragaman } \\
\text { Haplotipe }\end{array}$} & \multirow{2}{*}{$\begin{array}{l}\text { Keragaman } \\
\text { Nukleotida }\end{array}$} \\
\hline & & HA & $\mathrm{HB}$ & $\mathrm{HC}$ & HD & $\mathrm{HE}$ & $\mathrm{HF}$ & HG & & \\
\hline 1. & G. Buligir Putih & - & - & - & $\overline{-1}$ & - & $1,00-$ & - & 0,0000 & 0,0027 \\
\hline 2. & G. Kencana & - & - & 0,60 & & $0,40-$ & - & - & 0,5200 & 0,0027 \\
\hline 3. & G. Pasir Cangkuang & - & - & 0,20 & 0,20 & $0,40-$ & - & 0,20 & 0,7200 & 0,0138 \\
\hline 4. & G. Botol & 0,66 & 0,33 & - & - & - & - & - & 0,5445 & 0,0166 \\
\hline 5. & G. Kendeng & - & - & 0,33 & 0,66 & - & - & - & 0,5445 & 0,0027 \\
\hline 6. & G. Halimun Selatan & - & - & 1,00 & - & - & - & - & 0,0000 & 0,0027 \\
\hline & TNGH & & & & & & & & 0,7600 & 0,0222 \\
\hline
\end{tabular}

Keterangan. : TNGH (Taman Nasional Gunung Halimun)

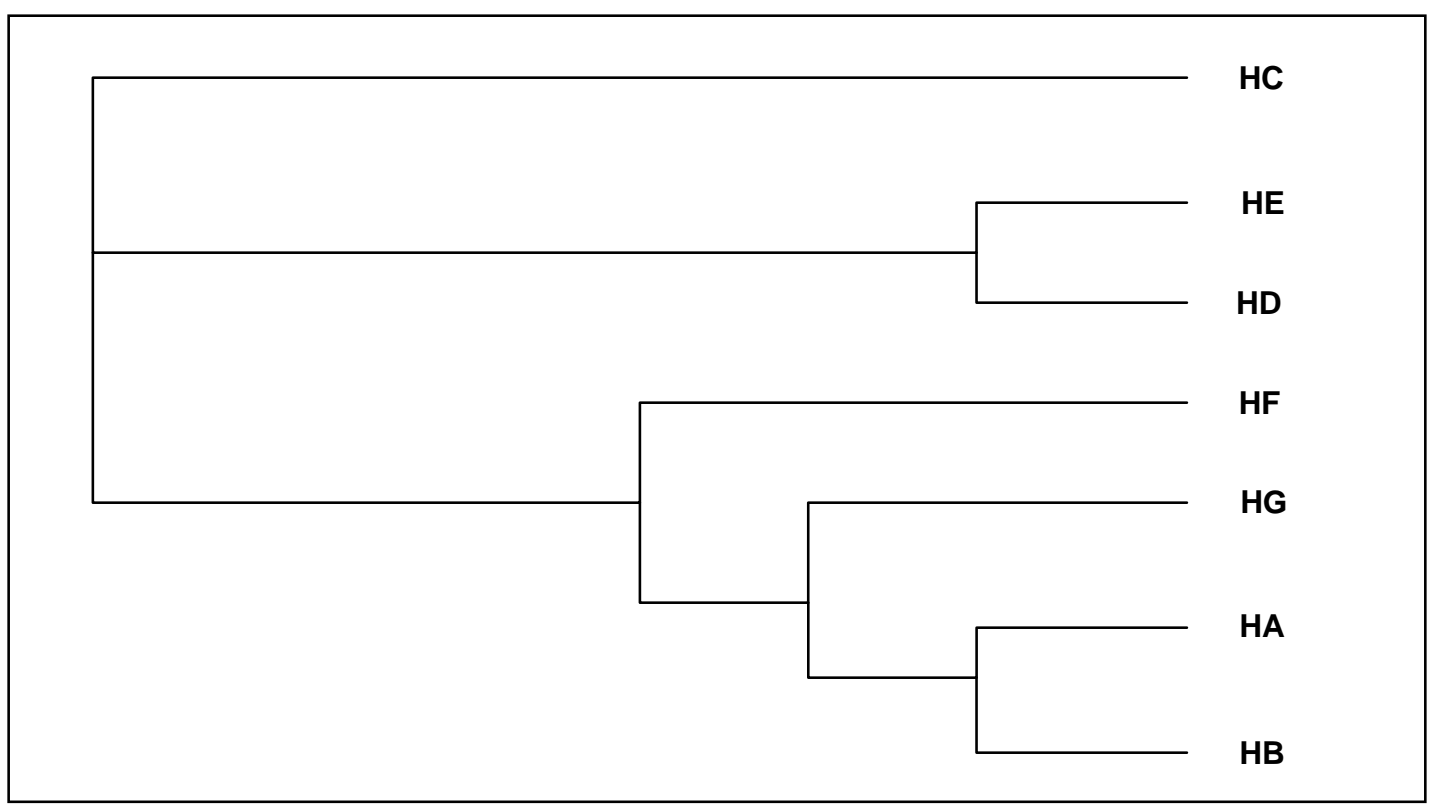

Gambar 3. Konstruksi pohon filogeni Chironax melanocephalus dengan menggunakan metoda Neighborjoining. Terdapat 7 haplotipe di Taman Nasional Gunung Halimun, yaitu: HA, HB, HC, HD, HE, $H F$, dan $H G$.

Tabel 2. Estimasi jarak genetik Chironax melanocephalus dengan metoda Kimura 2-parameter.

\begin{tabular}{crrrrrrr}
\hline Haplotipe & HA & HB & HC & HD & HE & HF & HG \\
\hline \hline HA & 0,0000 & & & & & & \\
HB & 0,0057 & 0,0000 & & & & & \\
HC & 0,0028 & 0,0028 & 0,0000 & & & & \\
HD & 0,0085 & 0,0085 & 0,0057 & 0,0000 & & & \\
HE & 0,0172 & 0,0172 & 0,0143 & 0,0143 & 0,0000 & & \\
HF & 0,0202 & 0,0202 & 0,0173 & 0,0173 & 0,0028 & 0,0000 & \\
HG & 0,0114 & 0,0202 & 0,0085 & 0,0085 & 0,0057 & 0,0086 & 0,0000 \\
\hline
\end{tabular}


Hasil keragaman genetik dengan menggunakan analisis sekuen DNA, menunjukkan fenomena yang menarik. Dilihat dari topografi Taman Nasional Gunung Halimun yang merupakan daerah pegunungan, diduga terdapat isolasi alam terhadap populasi Chironax melanocephalus yang mendominasi daerah mintakat sub pegunungan (1.000-1.500 $\mathrm{m}$ dpl). Pada umumnya antar populasi yang terisolasi menunjukkan keragaman genetik yang tinggi. Hal ini berkaitan dengan adanya genetic drift sebagai salah satu pendorong terjadinya evolusi. Selain itu populasi yang terisolasi biasanya mempunyai jumlah anggota kecil (Schmitt,1978). Hasil analisis keragaman genetik Chironax melanocephalus di Taman Nasional Gunung Halimun menunjukkan adanya 7 haplotipe. Hal ini menggambarkan tingkat keragaman yang tinggi. Daerah gunung Pasir Cangkuang mempunyai keragaman haplotipe yang paling tinggi $(0,72)$, dimana terdapat haplotipe $\mathrm{HC}, \mathrm{HD}$, $\mathrm{HE}$, dan $\mathrm{HG}$. Sedangkan daerah yang mempunyai keragaman haplotipe yang paling rendah adalah di gunung Halimun Selatan dan gunung Buligir Putih.

Haplotipe HC terdapat di sebagian besar lokasi pengambilan sampel, yaitu Gunung Kendeng, Gunung Halimun Selatan, Gunung Pasir Cangkuang, dan Gunung Kencana. Fenomena ini menunjukkan adanya aliran gen yang berasosiasi dengan kemampuan terbang yang cukup tinggi dan tidak terdapat penghalang geografi maupun habitat yang membatasi pergerakan Chironax melanocephalus di Taman Nasional Gunung Halimun. Kemungkinan lain adalah haplotipe tersebut berasal dari nenek moyang (ancestral) yang penyebarannya luas. Sebagaimana diketahui bahwa DNA mitokondria diturunkan secara maternal (Nei, 1987). Dengan demikian populasi kelelawar ini di Taman Nasional Gunung halimun tidak memperlihatkan fenomena adanya isolasi yang ditunjukkan dengan adanya keragaman haplotipe cukup tinggi dan penyebaran haplotipe yang merata.

Sebaliknya terjadi pada haplotipe HA dan HB yang hanya terdapat di Gunung Botol dan haplotipe HF di Gunung Buligir Putih. Pada haplotipe HA dan HB terdapat titik mutasi yang paling tinggi yaitu 6 dan 5 situs mutasi dari 355 runutan basa gen 12SrRNA yang dievaluasi (lihat Gambar 2). Fenomena ini diduga berhubungan dengan adanya perbedaan silsilah yang berasosiasi dengan kondisi lingkungan setempat yang menyebabkan adanya individu-individu di gunung Botol yang tidak menyebar ke tempat lain karena terikat pada mikrohabitat setempat. Kemungkinan lain yang dapat diduga adalah baru terjadinya mutasi pada situs yang polimorfik tersebut, sehingga penyebaran haplotipe HA, HB, dan HF sangat terbatas. Fenomena ini sering dijumpai pada jenis hewan terbang yang memiliki daerah sebaran luas (Avise et al., 1987).

Pola variasi genetik seperti ini juga dijumpai pada antar populasi kelelawar pemakan buah Eonycteris spelaea dari gua-gua di pulau Lombok yang menunjukkan sekaligus adanya haplotipe yang tersebar luas maupun yang hanya terdeteksi pada populasi tertentu saja (Hisheh et al., 1998). Oleh karena itu kemudian diduga bahwa populasi kelelawar Chironax melanocephalus di Taman Nasional Gunung Halimun mempunyai ukuran populasi efektif (effective population size) yang memadai untuk menjaga kesinambungan biodiversitas genetiknya. Selain itu, walaupun distribusinya terbatas pada daerah pegunungan, ternyata adanya migrasi akan mencegah terjadinya perbedaan genetik yang ditunjukkan dengan tingginya diversitas haplotipe. Hal ini juga diduga berkaitan dengan kemampuan terbang kelelawar ini yang cukup jauh sehingga mampu mengatasi isolasi geografis daerah pegunungan.

Parameter yang umum digunakan untuk menggambarkan variasi genetik adalah keragaman nukleotida. Keuntungan dengan menggunakan parameter keragaman nukleotida adalah tidak tergantung pada besarnya sampel dan panjang DNA (Hartl dan Clark, 1989). Berdasarkan publikasi yang ada, Nei (1987) menyatakan bahwa besarnya diversitas nukleotida pada DNA mitokondria bervariasi antara 0,002 sampai 0,019. Keragaman nukleotida paling tinggi dari 355 pasangan basa gen 12SrRNA dari DNA mitokondria yang dievaluasi di Taman Nasional Gunung Halimun terdapat di Gunung Botol $(0,0166)$ dan Gunung Pasir Cangkuang (0,0138). Daerah 
yang mempunyai keragaman nukleotida lebih rendah terdapat di Gunung Kendeng, Gunung Halimun Selatan, Gunung Buligir Putih, dan Gunung Kencana masing-masing 0,0027. Secara keseluruhan keragaman nukleotid di Taman Nasional Gunung Halimun adalah 0,0222, sedikit lebih besar dari pendapat Nei (1987). Penelitian antar gua populasi kelelawar Eonycteris spelaea di pulau Lombok dengan menggunakan control region (D-loop) dari DNA mitokondria sebagai bahan kajian, menunjukkan keragaman nukleotida yang lebih tinggi (Hisheh et al., 1998). Ditinjau dari data awal ini maka penelitian lebih lanjut dapat dilakukan dengan menggunakan D-loop sebagai kajian keragaman genetik.

Jarak genetik dari haplotipe dalam penelitian ini tidak terlalu besar, yaitu $0,0028-$ 0,0202 (Tabel 2.). Fenomena ini merupakan indikasi adanya aliran gen antar gununggunung di dalam kawasan Taman Nasional Gunung Halimun, sehingga membatasi terjadinya perbedaan variasi genetik. Storz (2002) menyatakan bahwa pengamatan terhadap bentuk variasi genetik mikrosatelit dari populasi kelelawar pemakan buah (Cynopterus sphinx) di Semenanjung India, menunjukkan adanya hubungan yang positip antara jarak genetik dan faktor geografi (isolation by distance) antar populasi. Hal ini akan lebih menarik jika populasi $C$. melanocephalus antar pegunungan yang jaraknya berjauhan dan terpisah digunakan sebagai bahan kajian lebih lanjut, untuk mengetahui kemampuan migrasi kelelawar ini.

\section{Kesimpulan}

Hasil penelitian ini menunjukkan pentingnya implikasi terhadap konservasi keragaman genetik. Populasi kelelawar $C$. melanocephalus di Taman nasional Gunung Halimun menunjukkan adanya keragaman genetik yang tinggi dalam suatu kawasan yang relatif sempit. Hal ini merupakan indikasi bahwa seluruh kawasan ini merupakan habitat penting bagi kelelawar jenis ini.

Kemampuan terbang kelelawar ini di seluruh kawasan pegunungan, memungkinkan terjadinya aliran gen antar populasi sehingga isolasi jarak geografi di kawasan ini relatip tidak berpengaruh secara signifikan. Selain itu tingkat keragaman genetik yang terdeteksi secara tidak langsung menunjukkan kelelawar ini di Taman Nasional Gunung Halimun mempunyai populasi (population size) yang memadai. Penelitian lanjutan untuk menghasilkan informasi lebih lengkap mengenai keragaman haplotipe $C$. melanocephalus dapat dilakukan dengan menggunakan control region (D-loop) dari DNA mitokondrial sebagai bahan kajian.

\section{Ucapan Terima Kasih}

Penulis menghaturkan rasa terima kasih yang sebesarnya-besarnya kepada Biodiversity Conservation Project (JICA) dan Dr Toshinao OKAYAMA (JICA expert) atas saran dan dukungannya dalam analisis DNA di laboratorium genetika, Bidang Zoologi, Pusat Penelitian Biologi-LIPI. Selain itu penulis mengucapkan terima kasih kepada Dr. Sri Sulandari dan Agus Kundarmasno sebagai teman sejawat yang selalu membantu dan meluangkan waktu untuk berdiskusi serta Dr.Sih Kahono yang memberikan dukungan dalam pengambilan sampel di Taman Nasional Gunung Halimun.

Kepala Taman Nasional Gunung Halimun telah memberikan ijin dan fasilitas selama penelitian. Sdr. Yusup, Bidang Zoologi, Pusat Penelitian Biologi-LIPI memberikan bantuan teknis selama kegiatan koleksi di lapang. Sdr. Jumadi dan Hetty membantu untuk penataan draft awal. Sdr. Apud, Hendi dan Suryana, ketiganya dari Desa Ciptalahap, membantu untuk kelancaran pekerjaan di lapang.

\section{Daftar Pustaka}

Alikodra, H.S. 1990. Pengelolaan Satwa Liar. Jilit I. Pusat Antar Universitas, Institut Pertanian Bogor. Bogor.

Anderson, S., A.T. Bankier, B.G. Barrell, M.H.L. De Bruijn, \& A.R. Coulson. 1981. Sequence and Organization of the Human Mitochondrial genome. Nature 290:457-465 
Avise, J.C. 1994. Molecular Markers, Natural History and Evolution. Chapman and Hall, New York.

Avise, J.C., J. Arnold, R. M. Ball, E. Bermingham, T. Lamb, J. E. Neigel, C. A. Reeb, \& N. C. Saunders. 1987. Intraspecific Phylogeography: the Mitochondrial DNA Bridge Between population Genetics and systematics. Annual Review of Ecology and Systematics 18:489-522.

Fujita, M.S. \& M. D. Tuttle. 1991. Flying Foxes (Chiroptera: Pteropodidae) : Threatened Animals of Key Ecological and Economical Importance. Conservation Biology 5:455-463.

Hartl, D. L. \& A. G. Clark. 1989. Principles of Population Genetics $2^{\text {nd }}$ ed. Sinauer Associates, Massachusetts.

Hisheh, S., M. Westerman \& L. H. Schmitt. 1998. Biogeography of the Indonesian Archipelago: Mitochondrial DNA Variation in the Fruit Bat, Eonycteris spelaea. Biological Journal of the Linnean Society 65:329-345.

Kitchener, D.J., A. Gunnell \& Maharadatunkamsi. 1990. Aspect of the Feeding Biology of Fruit Bat (Pteropodidae) on Lombok Island, Indonesia. Mammals 54(4):561-574.

Nei, M. 1987. Molecular Evolutionary Genetics. Columbia University Press, New York.

Payne, J., \& M. Francis. 1985. A Field Guide to the Mammals of Borneo. The Sabah Society. World Wildlife Fund Malaysia.

Sambrook, J., E.F. Fritsch \& T. Maniatis. 1989. Moleculer Cloning, A Laboratory manual. $2^{\text {nd }}$ Edition. Cold Spring Harbor Laboratory Press.
Schmitt, L. H. 1978. Genetic Variation in Isolated Populations of the Australian bush-rat, Rattus fuscipes. Evolution 32: $1-14$.

Shearer, T.L., M.J.H.V. Oppen, S.L. Romano, \& G. Worheide. 2002. Slow Mitochondrial DNA Sequence Evolution in the Anthozoa (Cnidaria). Molecular Ecology 11(12):2474-2487.

Simbolon, E., \& E. Mirwanto, 1997. Altitudinal Zonation of the Forest Vegetation in Gunung Halimun National Park, West Java. In : Yoneda, M., J. Sugardjito, \& Simbolon, H. Research and Conservation Biodiversity in Indonesia Vol II. The inventory of natural resources in Gunung Halimun National Park. pp.14-35. Biodiversity Conservation Project. JICA,LIPI and PHKA. Bogor.

Storz, J.F. 2002. Contrasting Patterns of Divergence in Quantitative Traits \& Neutral DNA Markers: Analysis of Clinal Variation. Molecular Ecology 11(12):2537-2551.

Suyanto, A. \& M. A. Sinaga, 1998. Note on Additional Collection of Small Mammals in Gunung Halimun National Park. In Simbolon, H., M. Yoneda, \& J. Sugardjito (Eds.).Research and Conservation Biodiversity in Indonesia Vol. IV. Gunung Halimun: The Last Submontane Tropical Forest in West Java. $\quad$ Pp 82-95. Biodiversity Conservation Project. JICA, LIPI and PHKA. Bogor

Suyanto, A., M. Yoneda, I. Maryanto, Maharadatunkamsi \& J. Sugarjito. 2002. Check List of Indonesian Mammals. $2^{\text {nd }}$ edition. Biodiversity Conservation Project. LIPI, JICA and PHPA, Bogor. 
